\title{
PENINGKATAN KEMAMPUAN MOTORIK HALUS KELOMPOK A MELALUI KEGIATAN SENI MELIPAT(ORIGAMI) TISSUE ROTI
}

\author{
Nurul Aminah \\ TK Aisyiyah 32 Mojo \\ Email: nurulamie.world@gmail.com
}

\begin{abstract}
ABSTRAK
Penelitian ini dilakukan berdasarkan temuan masalah yang berkaitan dengan motorik halus anak kelompok A di TK Aisyiyah 32 Mojo Surabaya.Permasalahan tersebut menuntut perlunya suatu solusi baik berupa pendekatan, metode atau model pembelajaran untuk menanganinya yaitu dengan pembelajaran seni melipat tissue roti. Hal tersebut mendasari adanya rumusan masalah, yaitu:(1) Bagaimana kegiatan kemampuan motorik halus anak melalui seni melipat di TK Aisyiyah 32?(2)Bagaimana hasil belajar kemampuan motorik halus anak melalui melipat di TK Aisyiyah 32. Tujuan dari penelitian ini untuk anak agar dapat mengontrol gerakan otot-otot kecil secara baik melalui kegiatan melipat dan untuk guru sebagai bahan referensi untuk mengetahui perkembangan motorik halus pada anak melalui kegiatan melipat.
\end{abstract}

Kata kunci: seni melipat / origami, motorik halus.

\section{ABTRACT}

This research was conducted based on the findings of problems related to fine motor children of group A in kindergarten Aisyiyah 32 Mojo Surabaya. These problems demanded the need for a solution in the form of approaches, methods or learning models to handle it, namely by learning the art of folding tissue bread. This underlies the existence of problem formulation, namely: (1) How are the activities of children's fine motor skills through the art of folding in kindergarten Aisyiyah 32? (2) What are the results of learning the children's fine motor skills through folding in kindergarten Aisyiyah 32. The purpose of this study is for children to can control the movement of small muscles well through folding activities and for teachers as a reference material to find out the development of fine motor skills in children through folding activities

Keyworld: art of folding / origami, fine motor skills

\section{Pendahuluan}

Anak usia dini adalah anak yang baru dilahirkan sampai usia 6 tahun. Usia ini merupakan usia yang sangat menentukan dalam pembentukan karakter dan kepribadian anak. Anak usia dini merupakan individu yang sedang mengalami pertumbuhan dan perkembangan sangat pesat. Masa ini ditandai oleh berbagai peristiwa penting dan fundamental dalam kehidupan anak sampai periode akhir perkembangannya (Novan, 2012:5).
Dalam Undang-undang SisDiknas Nomor 2 Tahun 2004, dalam undang-undang tersebut pendidikan diartikan sebagai usaha sadar dan terencana untuk mewujudkan suasana belajar dan proses pembelajaran agar peserta didik secara aktif mengembangkan potensi dirinya untuk memiliki kekuatan spiritual keagamaan, pengendalian diri, kepribadian, kecerdasan, akhlak mulia, serta 


\section{Nurul Aminah}

keterampilan yang diperlukan dirinya, masyarakat bangsa dan negara (Novan, 2013: 11).

Dalam Undang-undang Nomor 20 Tahun 2003 Bab I Pasal I Ayat 14 tentang sistem pendidikan nasional, dinyatakan bahwa pendidikan anak usia dini merupakan suatu upaya pembinaan yang ditunjukkan bagi anak yang dilakukan melalui pemberian rangsangan pendidikan untuk membantu pertumbuhan dan perkembangan jasmani dan rohani agar anak memiliki kesiapan dalam memasuki pendidikan lebih lanjut, yang diselenggarakan pada jalur formal, nonformal, dan informal (Novan, 2012:32).

Anak usia 0-6 ini merupakan golden age (usia emas) yang didalamnya terdapat "masa peka" yang hanya datang sekali. Masa peka adalah suatu masa yang menuntut aspek perkembangan anak untuk dikembangkan secara optimal. Mengingat pentingnya masa ini, maka peran stimulasi berupa penyediaan lingkungan yang tepat dan kondusif kondusif harus disiapkan oleh para orang tua, guru, pengasuh ataupun orang dewasa lain yang ada disekitar anak. Salah satu cara dengan menyediakan kegiatan yang sesuai perkembangan anak, sehingga anak memiliki kesempatan untuk mengembangkan seluruh potensinnya. Potensi yang dimaksud meliputi aspek moral dan nilai-nilai agama, sosial, emosional dan kemandirian, kemampuan berbahasa, kognitif, fisik/motorik dan seni. Perkembangan potensi - potensi ini diberikan pada awal kehidupan anak untuk dapat berkembang secara optimal (Depdiknas, 2007:1)

Perkembangan motorik diartikan sebagai perkembangan dari unsur kematangan dan pengendalian gerak tubuh. Ada tiga unsur yang menentukan dalam perkembangan motorik, yaitu otak, saraf, dan otot. Ketika motorik bekerja, ketiga unsur tersebut melaksanakan peranannya masing-masing secara interaksi positif. Artinya, unsur-unsur yang satu saling berkaitan, saling menunjang, saling melengkapi dengan unsur lainnya untuk mencapai kondisi motorik yang lebih sempurna keadaannya (Depdiknas, 2010:9).

Keterampilan koordinasi motorik atau otot halus menyangkut koordinasi gerakan jari-jari tangan dalam berbagai aktivitas, seperti : menggunting, memasang dan membuka kancing, meronce, melipat kertas dan lain-lain. Perkembangan motorik halus melibatkan otot kecil yang memungkinkan seperti melipat. Oleh karena itu, gerakan motorik halus tidak terlalu membutuhkan tenaga fisik, tetapi membutuhkan koordinasi yang cermat serta ketelitian (Kemendiknas, 2010:7)

Di masa awal kanak-kanak merupakan saat yang tepat untuk mempelajari banyak keterampilan. Mempelajari keterampilan motorik jauh lebih sulit, karena sulitnya menyuruh anak untuk berperan serta dalam eksperimen dan sulit melakukan pengamatan selama 
waktu yang diperlukan untuk menguasai suatu keterampilan.

\section{Pengertian Origami}

Origami adalah seni melipat kertas. Bahan yang digunakan adalah kertas atau kain yang biasanya berbentuk persegi. Origami merupakan hasil kerja tangan yang sangat teliti dan halus pada pandangan mata (Malik Tia, 2008:1).

Terdapat berbagai macam origami paper atau kertas yang dapat digunakan membuat origami. Berikut beberapa diantaranya:

Terdapat berbagai macam origami paper atau kertas yang dapat digunakan membuat origami. Berikut beberapa diantaranya:

a. Kertas Washi

Washi disebut juga dengan nama Wagami. Kertas ini merupakan kertas lokal jepang yang banyak digunakan oleh masyarakat Jepang dalam membuat origami. Kertas ini dibuat dengan metode tradisional di Jepang. Washi mempunyai tekstur yang lebih tipis dan indah namun tetap kuat serta tahan lama.

b. Kertas Irogami

Kertas Irogami adalah kertas yang saat ini paling umum digunakan untuk membuat origami. Kertas irogami dikenal juga sebagai kertas standar origami. Kertas ini memiliki banyak variasi dan kertas origami dibuat dengan berbagai macam warna.

c. Kertas Chiyogami
Kertas Chiyogami adalah kertas yang dibuat dengan corak yang menarik. Kertas ini sangat umum digunakan sebagai bahan membuat origami di negri Sakura. Tekstur, pola, warna, dan corak kertas Chiyogami dibuat sangat beragam.

d. Kertas Tissue

Kertas Tissue atau kertas selampai adalah jenis kertas krep ringan yang dapat digunakan untuk berbagai tujuan, seperti kertas tissue higienis, tissue wajah(facial tissue), handuk kertas, kertas pembungkus, dan lainnya. Kertas tissue dapat dibuat dari bubur kertas asli maupun hasil daur ulang.

Kertas tissue digunakan untuk membuat berbagai produk yang memiliki sifat dan kebutuhan mutu yang berbeda, yang mencakup kekuatan, daya serap, berat dasar, ketebalan, kecerahan, kiah, rupa,dll

\section{Seni Melipat (origami)}

Seni melipat atau origami merupakan seni melipat berasal dari jepang. Kata origami berasal dari dua suku kata "ori" yang artinya melipat dan "kami: yang berarti kertas.

Sejak origami bermula sejak manusia muali memproduksi kertas. Kertas pertamakali diproduksi di tiongkok pada abad pertama dan diperkenalkan oleh Ts'ai Lun. Kemudian pada abad keenam, seorang biksu budha bernama Doncho (Dokyo) yang berasal dari Gugoryeo (Semenanjung Korea) 


\section{Nurul Aminah}

memperkenalkan kertas dan tinta di jepang pada masa pemerintahan kaisar wanita Suiko. Sejak itu, origami mulai berkembang dan menjadi begitu popular di Jepang sampai hari ini.

Salah satu keunikan origami terletak pada hasil akhir pelipatan. Lipatan kertas yang dibentuk sedemikian rupa bisa terlihat menarik dengan berbagai jenis obyek yang diinginkan. Origami sudah menajdi aspek yang penting dalam perayaan-perayaan di jepang sejak periode Heian. Jimat yang dipercaya dan dibawa oleh para Samurai (Noshi) pun juga berupa origami. Selain itu, origami kupu-kupu juga digunakan di dalam upacara perkawinan adat agama Shinto.

Pada abad keenam, selain di jepang, origami ini dibawa dan diperkenalkan juga di Spanyol. Hingga kini, seni origami sudah sangat popular di Indonesia. Kebanyakan anak-anak TK dan SD sudah diajarkan cara membuat bermacam-macam bentuk dari kertas lipat atau origami paper. Dengan bermacam-macam warna (merah, kuning, orange, ungu, dan hijau) mampu menarik perhatian anak-anak kecil untuk mau mencoba membuat berbagai bentuk, seperti membuat kapal, topi, kincir angin, dan pesawat.

\section{Motorik Halus}

\section{Pengertian Motorik Halus}

Motorik halus adalah meningkatnya pengoordinasian gerak tubuh yang melibatkan otot dan syaraf yang jauh lebih kecil atau detail. Kelompok dan syaraf inilah yang nantinya mampu mengembangkan gerak motorik halus, seperti meremas, melipat kertas, menggambar, menulis dan lain sebagainya (Suyadi, 2010:69).

\section{Fungsi Perkembangan Motorik Halus}

Hurlock mencatat beberapa alasan tentang fungsi perkembangan motorik bagi konstelasi perkembangan individu, yaitu :

Pertama, melalui keterampilan motorik halus, peserta didik di TK dapat menghibur dirinya dan memperoleh perasaan senang.

Kedua, melalui keterampilan motorik halus, peserta didik di TK dapat beranjak dari kondisi helplessness (tidak berdaya) pada bulan-bulan pertama kehidupannya ke kondisi yang independence (bebas, tidak bergantung).

Ketiga, melalui keterampilan motorik, peserta didik di TK dapat menyesuaikan dirinya dengan lingkungan sekolah (school adjustment). Pada usia persekolah (taman kanak-kanak) atau usia kelas di sekolah dasar, peseta didik sudah dapat dilatih menggambar, melukis, baris-berbaris, dan persiapan menulis.

\section{Karakteristik Perkembangan Motorik Halus \\ Karakteristik keterampilan motorik peserta didik di TK dapat dijelaskan sebagai berikut.}


Pertama, pada saat peserta didik di TK berusia 3 tahun, kemampuan gerakan halus peerta didik belum terlalu berbeda dari kemampuan gerakan halus pada masa peserta didik masih bayi

Kedua, pada usia 4 tahun, koordinasi motorik halus peserta didik di TK secara substansial sudah mengalami kemajuan dan gerakannya sudah lebih cepat, bahkan cenderung ingin sempurna.

Ketiga, pada usia 5 tahun, koordinasi motorik halus peserta didik di TK sudah lebih sempurna lagi. Tangan, lengan, dan tubuh bergerak di bawah koordinasi mata.

Keempat, pada akhir masa kanak-kanak (usia 6 tahun), peserta didik di TK telah belajar bagaimana menggunakan jari-jemari dan pergelangan tangan ntuk menggerakkan ujung pensil.

\section{Tahap-tahap perkembangan motorik halus}

Tahap-tahap Perkembangan Motorik Halus anak usia 4 tahun menurut (Mirroh, 2013:47):

- Membuat garis vertikal, horizontal, lengkung kiri/kanan, miring kiri/kanan, dan lingkaran

- Menjiplak bentuk

- Mengkoordinasikan mata dan tangan untuk melakukan gerakan yang rumit

- Melakukan gerakan manipulative untuk menghasilkan suatu bentuk dengan menggunakan berbagai media
- Mengekspresikan diri dengan berkarya seni menggunakan berbagai media

- Melipat kertas membentuk segitiga (Fina, 2016: 67)

\section{Implementasi Seni Melipat Terhadap Perkembangan Motorik Halus}

a. Pelaksanaan Pengembangan Seni Lipat

Pengembangan seni merupakan wahana untuk mengembangkan berbagai bidang pengembangan kemampuan dasar yang dipersiapkan oleh guru untuk meningkatkan kemampuan dan kreativitas peserta didik di TK sesuai dengan tahap perkembangan mereka. Pengembangan seni bertujuan agar peserta didik di TK dapat menciptakan sesuatu berdasarkan hasil imajinasinya, mengembangkan kepekaan, dan dapat menghargai hasil karya yang kreatif.

\section{Tahapan Kegiatan Melipat}

\section{i. Pengenalan Berbagai Jenis Kertas dan Daun.}

Tujuan kegiatan ini adalah agar anak mengenal berbagai jenis kertas dan daun. Dengan demikian, anak akan dirangsang untuk berkreativitas membuat berbagai bentuk lipatan

\section{ii. Peserta Didik Diperkenalkan dengan Bermacam-macam Lipatan Dasar}

Pada kegiatan ini anak diperkenalkan beberapa macam lipatan dengan kertas lipat. 


\section{Nurul Aminah}

Cara membuat lipatan dasar garis miring :

Kertas origami dilipat dengan mempertemukan satu sudut antara sudut kanan dan sudut kiri yang berseberangan. Cara melipatnya, yaitu jari telunjuk menekan ujung kertas atau sudut yang dipertemukan dengan jari tengah bersama jari jempol tangan kanan menjepit sudut kertas atas ditarik ke sudut bawah kertas. Tahan kertasnya oleh jari telunjuk dan jari tengah kiri tangan. Lipatan yang terbentuk ditekan dan ditarik dengan jempol kanan dari kiri ke kanan. Terbentuklah lipatan gunung dengan lipatan satu.

\section{b. Manfaat Melipat/Origami}

Pertama, seni melipat berperan untuk mengembangkan motorik halus.

Kedua, merangsang kreativitasdan imajinasi

Ketiga, mengasah mental geometric Keempat, mengasah mental menjadi tekun, telaten dan sabar

Kelima, media komunikasi

Keenam, keterampilan

Ketujuh, deteksi dini.

\section{Metode penelitian}

Penelitian ini merupakan penelitian tindakan kelas yang dilakukan secara kolaboratif. Artinya penelitian tidak melakukan penelitian sendiri namun bekerja sama dengan guru kelas yang lain. Jenis penelitian ini adalah menggunakan metode prosedur Penelitian Tindakan Kelas
(PTK) di TK Aisyiyah 32 Surabaya, mengungkapkan adanya upaya meningkatkan kemampuan motorik halus anak melalui kegiatan seni melipat(origami) tissue roti, secara sistematis dan akurat. Menurut pandapat Kemmis dalam Wrahatnolo (2009:3), PTK adalah penelitian yang dilakukan oleh guru di kelasnya sendiri melalui refleksi diri dengan tujuan untuk memperbaiki kinerjanya sebagai guru, sehingga perkembangan anak menjadi meningkat.

Sedangkan menurut pendapat Hopkins, dalam Setianingsih (2008:1), PTK merupakan suatu bentuk kajian bersifat reflektif yang dilakukan oleh pelaku tindakan untuk meningkatkan kemantapan tindakan mereka dalam melakukan tugas, memperdalam pemahaman terhadap tindakan yang dilakukan, serta memperbaiki kondisi dimana praktek pembelajaran tersebut dilakukan.

Adapun tujuan penelitian ini adalah untuk mengetahui upaya peningkatan kemampuan motorik halus, melalui kegiatan seni melipat(origami) tissue roti kelompok A TK Aisyiyah 32 Surabaya. Dalam PTK dikenal adanya siklus pelaksanaan yang berpola perencanaan, pelaksanaan, observasi, refleksi, revisi (perencanaan ulang).

Desain penelitian mengikuti empat pola yang meliputi : perencanaan, pelaksanaan, observasi dan refleksi pada setiap siklus. 
Desain penelitiannya dapat digambarkan sebagai berikut :

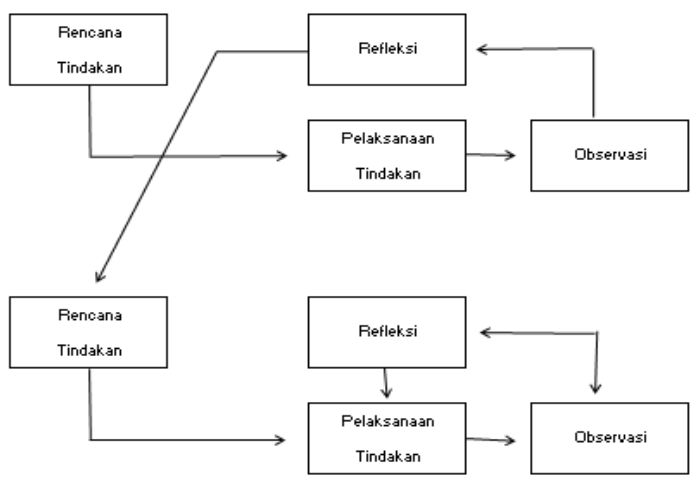

Gambar

Siklus pelaksanaan kegiatan

penelitian menurut Kemmis

(1995:35)

\begin{tabular}{|c|l|c|c|c|c|}
\hline 3 & $\begin{array}{l}\text { Memberi penjelasan kepada anak } \\
\text { tentang kegiatan pembelajaran yang } \\
\text { akan dilakukan }\end{array}$ & & $\checkmark$ & & \\
\hline 4 & $\begin{array}{l}\text { Memberikan penjelasan dan } \\
\text { demonstrasi cara melipat kertas } \\
\text { tissue roti }\end{array}$ & & $\checkmark$ & & \\
\hline 5 & $\begin{array}{l}\text { Memberikan kesempatan anak untuk } \\
\text { berlatih sendiri kegiatan melipat } \\
\text { dengan tissue roti }\end{array}$ & & $\checkmark$ & & \\
\hline 6 & $\begin{array}{l}\text { Membimbing anak yang mengalami } \\
\text { kesulitan dalam melipat kertas tissue } \\
\text { roti }\end{array}$ & & $\checkmark$ & & \\
\hline 7 & $\begin{array}{l}\text { Menciptakan suasana pembelajaran } \\
\text { yang menyenangkan }\end{array}$ & & & $\checkmark$ & \\
\hline 8 & $\begin{array}{l}\text { Memberi variasi suara saat } \\
\text { pembelajaran }\end{array}$ & & & $\checkmark$ & \\
\hline 9 & $\begin{array}{l}\text { Memberikan penghargaan atau } \\
\text { pujian kepada anak }\end{array}$ & & & $\checkmark$ & \\
\hline 10 & $\begin{array}{l}\text { Memberikan penegasan dan Tanya } \\
\text { jawab tentang kegiatan dan materi } \\
\text { pembelajaran yang telah dilakukan }\end{array}$ & & & $\checkmark$ & \\
\hline & Jumlah & 0 & 12 & 12 & 0 \\
\hline
\end{tabular}

\section{Hasil Penelitian}

\section{Tahap Pelaksanaan Tindakan}

Pada tahap awal pelaksanaan, diawali dengan menyusun Rencana Kegiatan Harian (RKH) disesuaikan dengan tema pada yang ada pada semester 1. Menyiapkan kertas lipat, membuat lembar observasi untuk pengamatan terhadap aktivitas guru dan aktivitas siswa pada saat pembelajaran berlangsung, membuat instrument kemampuan motorik halus anak melalui kegiatan melipat. Mengatur alokasi waktu selama proses pembelajaran dengan alokasi waktu, sebagai berikut:

\section{Hasil Observasi}

Dari hasil penelitian pada siklus I pertemuan 1 dapat disimpulkan bahwa kemampuan melipat kertas meniru bentuk buku dengan kertas tissue roti masih perlu bimbingan. Peneliti beranggapan guru kurang menguasai anak-anak ketika melipat karena anak-anak masih baru pembelajaran selama 2 bulan jadi anak-anak masih belum fokus memperhatikan guru. Guru diharapkan lebih bisa menguasai kelas dalam memberikan contoh kepada anak tentang kertas melipat dengan kertas tissue roti. Agar anakanak biasa melipat dengan baik dengan kertas tissue roti.

Tabel 4.1

\begin{tabular}{|c|l|c|c|c|c|}
\hline \multirow{2}{*}{ No } & \multicolumn{1}{|c|}{ Aspek } & \multicolumn{4}{|c|}{ Hasil Penelitian } \\
\cline { 3 - 6 } & & 1 & 2 & 3 & 4 \\
\hline 1 & $\begin{array}{l}\text { Menyapa dan memberikan salam } \\
\text { kepada anak }\end{array}$ & & $\checkmark$ & & \\
\hline 2 & Memberi motivasi kepada anak & & $\checkmark$ & & \\
\hline
\end{tabular}




\section{Nurul Aminah}

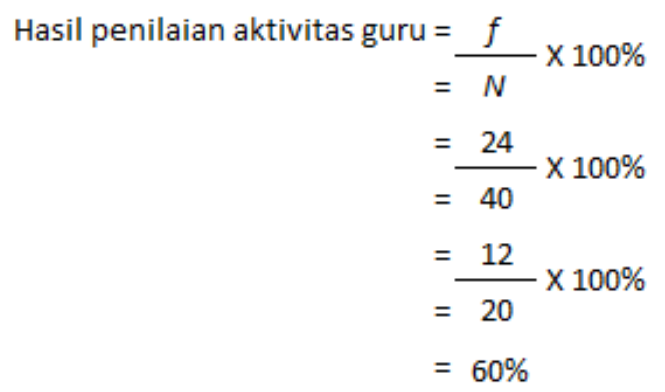

\section{Siklus II}

\section{Penyusunan Rencana Tindakan}

Dalam menyusun rencana tindakan pada siklus II dilaksanakan bersama teman sejawat setelah sebelumnya peneliti melakukan penuh pemikiran berdasarkan hasil pada siklus I. Peneliti menyiapkan Rencana Kegiatan Harian (RKH) dan kertas tissue roti, hiasan dari kertas lipat dan lem.

Kemudian mempersiapkan pedoman observasi yang akan digunakan dalam mengamati kegiatan pembelajaran dari kegiatan awal sampai akhir yang dilakukan guru dalam melaksanakan proses pembelajaran.

\section{Pelaksanaan Tindakan}

Pelaksanaan kegiatan pembelajaran untuk siklus II dilaksanakan pada kelompok A di TK Aisyiyah 32 Mojo Surabaya. Peneliti sekaligus guru juga mempersiapkan lembar observasi guru, lembar kemampuan anak dalam kegiatan seni melipat (origami) dengan tissue roti. Anakanak melipat bentuk amplop dan anak anak terlihat tertarik pada tema ini karena anak-anak terlihat menyukai amplop. Anak yang mengikuti pembelajaran melipat (origami) dengan tissue roti berjumlah 20 anak.

\section{Hasil Observasi}

Observasi meliputi pengamatan situasi Kegiatan Belajar Mengajar (KBM), Aktivitas Anak, Aktivitas Guru dan Kemampuan Anak dalam melakukan kegiatan melipat. Hasil observasi yang dilakukan pada saat proses pembelajaran berlangsung menghasilkan data siklus II yang dirangkum dalam tabel dibawah ini :

\begin{tabular}{|c|c|c|c|c|c|}
\hline \multirow[t]{2}{*}{ No } & \multirow{2}{*}{$\begin{array}{c}\text { Aspek Yang } \\
\text { Dimengerti }\end{array}$} & \multicolumn{4}{|c|}{ Hasil Pengamatan } \\
\hline & & 1 & 2 & 3 & 4 \\
\hline 1 & $\begin{array}{lr}\text { Menyapa } & \text { dan } \\
\text { memberikan } & \text { salam } \\
\text { kepada anak } & \end{array}$ & & & $\checkmark$ & \\
\hline 2 & $\begin{array}{l}\text { Memberi motivasi } \\
\text { kepada anak }\end{array}$ & & & & $\checkmark$ \\
\hline 3 & $\begin{array}{l}\text { Memberi penjelasan } \\
\text { kepada anak tentang } \\
\text { kegiatan pembelajaran } \\
\text { yang akan dilakukan }\end{array}$ & & & & $\checkmark$ \\
\hline 4 & $\begin{array}{lr}\text { Memberikan } & \\
\text { penjelasan dan } \\
\text { demonstrasi cara } \\
\text { melipat kertas } \\
\text { rotissue }\end{array}$ & & & & $\checkmark$ \\
\hline 5 & $\begin{array}{l}\text { Memberikan } \\
\text { kesempatan anak } \\
\text { untuk berlatih sendiri } \\
\text { kegiatan melipat } \\
\text { dnegan tissue roti }\end{array}$ & & & $\checkmark$ & \\
\hline 6 & 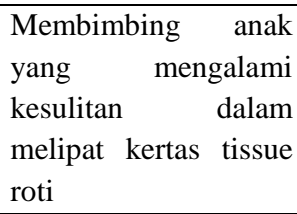 & & & & $\checkmark$ \\
\hline 7 & $\begin{array}{lr}\text { Menciptakan } & \text { suasana } \\
\text { pembelajaran } & \text { yang } \\
\text { menyenangka } & \end{array}$ & & & $\checkmark$ & \\
\hline 8 & $\begin{array}{l}\text { Memberi variasi suara } \\
\text { saat pembelajaran }\end{array}$ & & & $\checkmark$ & \\
\hline 9 & $\begin{array}{l}\text { Memberikan } \\
\text { penghargaan atau } \\
\text { pujian kepada anak }\end{array}$ & & & & $\checkmark$ \\
\hline
\end{tabular}




\begin{tabular}{|c|c|c|c|c|c|c|}
\hline 10 & $\begin{array}{l}\text { Memberikan } \\
\text { penegasan dan Tanya } \\
\text { jawab tentang } \\
\text { kegiatan dan materi } \\
\text { pembelajaran yang } \\
\text { telah dilakukan }\end{array}$ & & & & & $\begin{array}{l}\text { loti jadi lebih bervarisi bisa juga } \\
\text { dnegan kertas buku tulis biasa } \\
\text { tergantung kreasi guru. Karena } \\
\text { apabila gurunya kreatif anak-anak } \\
\text { juga akan semakin tertarik untuk }\end{array}$ \\
\hline & Jumlah & 0 & 0 & 12 & 24 & \\
\hline
\end{tabular}

$$
\begin{aligned}
\text { Hasil Penilaian Aktivitas Guru } & =\frac{f}{N} \times 1 \\
& =36 \\
& =40 \\
& =11 \\
& =20 \\
& =90 \%
\end{aligned}
$$

\section{Pembahasan Hasil Penelitian} Peningkatan Kemampuan Anak

Penelitian yang telah dilakukan di TK Aisyiyah 32 Mojo Surabaya dengan kegiatan seni melipat (origami) dengan tissue roti untuk meningkatkan motorik halus anak telah berjalan dengan baik. Penelitian ini dilakukan dengan dua siklus yaitu siklus I dan siklus II.

Penelitian ini mendukung beberapa teori, Diantaranya adalah teori Sugianto, (1995 : 31) yang mengatakan bahwa aspek motorik halus juga dapat dikembangkan melalui kegiatan bermain. Salah satu contoh, bisa diamati pada anak yang bermain melipat kertas. Pada awalnya ia belum terampil untuk melipat kertas, tetapi dengan bermain origami, maka anak berminat untuk melakukannya dan menjadi lebih terampil.

Melipat juga tidak harus dengan kertas lipat yang berwarna tapi juga bisa dengan kertas tissue
Hasil yang diperoleh setelah dilakukan penelitian dua siklus, ternyata dari 20 anak terdapat 16 anak termasuk dalam kategori baik dan 4 anak termasuk dalam kategori cukup. Kesimpulannya, Kemampuan motorik halus anak dapat ditingkatkan dengan kegiatan seni melipat(origami) menggunakan tissue roti. Dan seorang guru harus benar memperhatikan anak-anak dalam kegiatan melipat tersebut.

\section{Kesimpulan}

Penelitian ini dilakukan melalui dua siklus, yaitu siklus I dan siklus II dapat dilihat di bab pembahasan. Kesimpulannya bahwa kegiatan melipat dengan tissue roti dapat meningkatkan motorik halus anak di TK Aisyiyah 32 Mojo Surabaya.

Pada siklus I dari 20 anak terdapat anak yang masih kurang sebanyak 4 anak, lalu terdapat 2 anak saja yang baik dan 14 anak yang masuk dalam kategori cukup. Setelah siklus II dilaksanakan hampir tidak ada anak yang kurang. Hanya 4 anak yang termasuk kategori cukup dan 16 anak sudah termasuk kategori baik. Prosentasi naik 30\% Karena di siklus I hampir semua $60 \%$ sampai $65 \%$ dan di siklus II hamper nilai mencapai $80 \%$ sampai $90 \%$. 


\section{Nurul Aminah}

Dalam kegiatan melipat seharusnya guru lebih kreatif dengan menggunakan media agar anak lebih tertarik untuk melipat, salah satunya dengan menggunakan tissue roti. Dan guru lebih memperhatikan anakanak ketika melipat agar anak tidak salah,lebih teliti dan sabar ketika melipat.

\section{Daftar Pustaka}

Abdurrahman, Mulyono. 2012. Anak Berkesulitan Belajar. Jakarta: Rineka Cipta.

Anggraini, fina surya. 2016. Perkembangan Motorik AUD Teori dan Aplikasi. Surabaya: Kurnia Group Publishing. Arikunto, Suharsimi. 2010. Prosedur Penelitian. Jakarta: RinekaCipta

Fakhruddin, Asef Umar. 2010. Sukses Menjadi Guru TKPAUD. Jogjakarta: Bening. Sugiyono.2010. Metode Penelitian Pendidikan Pendekatan Kuantitatif, Kualitatif, dan $R \& D$. Bandung : Alfabeta. Susanto,

Ahmad.2011.Perkembangan

Anak Usia Dini. Jakarta:

Kencana Perdana Media Grup.

Sustiwi, Atik.2009.Seni Origami Bentuk Dasar.Yogyakarta: Rumah Pengetahuan.

Suyadi, 2010. Psikologi Belajar PAUD . Yogyakarta: PT Bintang Pustaka Abadi.

Trianto. 2011.

Desain

Pengembangan

Pembelajaran

Tematik.
Fikriyati, Mirroh. 2013. Usia Emas. Yogyakarta: Laras Media Prima.

Hawadi, Reni Akbar.2001.Psikologi Perkembangan Anak. Jakarta: PT Grasindo.

Kemendiknas.2009.Peraturan

Menteri Pendidikan Nasional Republik Indonesia

Nomor58.Jakarta: Menteri

Pendidikan Nasional.

Malik, Tia.2008. Mari Membuat Origami.Surabaya: Insan Cendekia.

Mulyasa.2012. Manajemen

PAUD.Bandung: PT Remaja Rosdakarya.

Salsabilla, Cindy. Th. Seni Melipat Kertas Origami.Surabaya: Serba Jaya.

Jakarta: Kencana Perdana Media Grup.

W. Santrock, john. 2007. Perkembangan anak. Jakarta: Erlangga.

Wiyani, Novan Ardy dkk.2012. Format PAUD. Yogyakarta: Ar-Ruzz Media. 